\title{
Comparison of the characterization of allergenic protein 3 (Pla a3) released from Platanus pollen grains collected in Shanghai during the spring of 2019 and 2020
}

\author{
Xingzi Wang $\cdot$ Shumin Zhou $\cdot$ Senlin Lu $\cdot$ Lu Zhang $\cdot$ Teng Ma $\cdot$ \\ Xinchun Liu $\cdot$ Wei Zhang $\cdot$ Shuijun Li $\cdot$ Kai Xiao - Weqian Wang • \\ Qingyue Wang
}

Received: 13 March 2021 / Accepted: 8 November 2021 / Published online: 27 November 2021

(C) The Author(s), under exclusive licence to Springer Nature B.V. 2021

\begin{abstract}
Due to the COVID-19 pandemic in early 2020, large-scale industrial production has been stagnant and reduced, the urban air quality has been greatly improved. It provided an excellent opportunity to explore the effects of air pollutants on the sensitization of pollen allergen proteins in the environment. Platanus pollen grains sampled in the spring
\end{abstract}

Wang Xingzi and Zhou Shumin have been contributed equally to the work.

Supplementary Information The online version contains supplementary material available at https://doi.org/10.1007/s10453-021-09731-6.

X. Wang $\cdot$ S. Zhou $\cdot$ S. Lu $(\bowtie) \cdot$ L. Zhang $\cdot$ T. Ma

School of Environmental and Chemical Engineering,

Shanghai University, Shanghai 200444, China

e-mail: senlinlv@staff.shu.edu.cn

S. Zhou - W. Zhang

Lab of Plant Cell Biology, Shanghai Key Laboratory of Bio-Energy Crops, School of Life Sciences, Shanghai University, Shanghai 200444, China

\section{Liu (ه)}

Institute of Desert Meterorology, China Meteorological Administration, Urumqi 83002, China

e-mail: liuxch@idm.cn

S. Li

Shanghai Xuhui Center Hospital, Shanghai 200031, China

K. Xiao $\cdot$ W. Wang $\cdot$ Q. Wang

School of Science and Engineering, Saitama University, Saitama 338-8570, Japan of 2019 and 2020 were used for detailed characterization and analysis. Scanning electron microscopy, Fourier transform infrared, X-ray spectroscopy (XPS), trypan blue staining, and western blot analysis were employed to characterize Platanus pollen protein released from pollen grains. Our data showed that the viability of the pollen grains in 2019 was lower compared that in 2020, and the pollen grains collected in 2019 had a higher absorption peak of protein functional groups. The XPS spectra assay result demonstrated that the binding energy of the high-resolution components had not variation on the surface of pollen grains, but relative content of nitrogen and peptide chain in the pollen grains sampled in 2019 were higher than in 2020. These results suggested that more protein in the pollen grains was released onto the surface of pollen grains. In addition, western blot assay showed that the expression of Pla a3 protein in pollen grains sampled in 2019 was significantly higher than that in 2020, revealing that air pollutants could enhance the expression of Pla a3 proteins in Platanus pollen.

Keywords Air pollution · Pollen allergen ·

Platanus pollen

\section{Introduction}

Previous studies have confirmed the existence of a close relationship between air pollutants and 
respiratory allergic diseases, with pollutants exerting an adjuvant or aggravating effect on the sensitization and elicitation phases of allergic immune responses (Acciani et al., 2013; D'Amato et al., 2007; Dahl, 2018; Leung et al., 2012). Air pollutants have been shown to affect allergens, interrupt gene expression, and modify membrane structures (Chauhan et al., 2004; Tashpulatov et al., 2004). Meanwhile, ambient particles tend to accumulate on the surface of pollen grains and change their shape and apparent features during the flowering season. For example, air pollutants have an effect on the maximum absorption values of each functional group (e.g., lipids and proteins) of the Zinnia pollen, which constitutes the chemical structure of the pollen (Chehregani et al., 2004). Furthermore, when exposing Platanus pollen to air pollutants, the FTIR spectral characteristics of functional groups also changes (Helena et al., 2017).

Since late 2019, coronavirus disease 2019 (COVID-19), which can spread rapidly among all age groups, has become a major global public health challenge (Xu et al., 2020). To suppress COVID-19, the Chinese government has implemented various stringent measures, such as issuing travel restrictions and suspending industrial production (Griffifiths et al., 2020), to prevent the spread of the virus. It is gratifying to note that these measures have objectively improved the ambient air quality in many Chinese cities. The mass concentrations of five air pollutants $\left(\mathrm{SO}_{2}, \mathrm{PM}_{2.5}, \mathrm{PM}_{10}, \mathrm{NO}_{2}\right.$, and $\left.\mathrm{CO}\right)$ decreased by $6.76 \%, 5.93 \%, 13.66 \%, 24.67 \%$, and $4.58 \%$, respectively (Wang and $\mathrm{Su}$ 2020). Many studies have confirmed the significant effects of $\mathrm{NO}_{2}$ and $\mathrm{O}_{3}$ on pollen and its intrinsic allergenic proteins under simulated laboratory conditions (Hong et al., 2018; Hu et al., 2020; Zhao et al., 2016). The significant difference in the mass level of air pollutants in Shanghai's atmosphere during the same period between 2019 and 2020 provides us with a rare opportunity to verify the actual effects of air pollutants on the allergenicity of pollen proteins.

Platanus tree is widely planted in the urbanized areas of China. Three important allergens, Pla a1, Pla a2, and Pla a3, are present in Platanus pollen (Arilla et al., 2005; Asturias et al., 2002; Suárez-Cervera et al., 2005). Pla a1 is an $18-\mathrm{kDa}$ non-glycosylated protein, Pla a2 is a 43-kDa glycoprotein, and Pla a3 is a non-specific lipid transfer protein. Even if Pla a1 and Pla a 2 are the major pollen allergens in plane pollen (Fernández et al., 2013), the role of Pla a3 in causing pollen allergies cannot be ignored. In addition, Pla a3 is a non-specific lipid transporter that contributes significantly to maintaining the integrity and function of the pollen cell membrane. The expression of $\mathrm{Pla}$ a3 protein is significantly influenced by environmental factors, such as $\mathrm{NO}_{2}$ and $\mathrm{O}_{3}$ (Zhou et al., 2021). A large amount of airborne Platanus pollen is released into the environment during the annual flowering period (March-May). Our previous study showed the release of allergenic proteins into the air after pollen grains were hydrated (Wang et al., 2012). Based on the above facts, we collected fresh pollen grains from the Platanus tree planted near Shangda Road in Shanghai in the spring of 2019 and 2020. Combined with the analysis of the mass level of major air pollutants during the sampling period, we tried to explore its impact on the prevalence of pollen allergenicity leading to air quality improvement and provide fundamental data to elucidate the mechanism of pollinosis induced by ambient allergens.

\section{Materials and methods}

\subsection{Platanus pollen sampling}

The inflorescences of Platanus were collected at the sampling site $\left(121^{\circ} 23^{\prime} \mathrm{E} 31^{\circ} 19^{\prime} 00.20^{\prime \prime} \mathrm{N}\right)$ (Figure S1) from April 5 to 20, 2019, and April 5 to 20, 2020, respectively. The collected inflorescences were spread in a clean tray at room temperature for 2 days. While pollen grains were scattered on the tray, pollen grains were separated using a sieve with $40 \mu \mathrm{m}$ mesh. Pollen grains were then placed in a 15-ml Eppendorf tube, sealed and stored at $-20{ }^{\circ} \mathrm{C}$. Pollen samples were taken from a sample of ten Platanus acerifolia trees at the sampling point on Shangda Road, and the total amounts of pollen collected in 2019 and 2020 were $8.924 \mathrm{~g}$ and $8.487 \mathrm{~g}$, respectively.

\subsection{Scanning electron microscopy}

The detailed process was carried out according to the protocol described by Lu et al. (2008). Briefly, $0.1 \mathrm{~g}$ of pollen grain was placed on a double-sided adhesive and conductive carbon tape with a clean wooden 
pick. Following this step, air was gently blown to remove the loosely stuck pollen from the carbon tape.

After covering the carbon tape with gold, the sample was observed under a Zeiss ultra 55 FE-SEM scanning electron microscope (Zeiss, Germany) with the following parameters: voltage of $30 \mathrm{kV}$, resolution of $3 \mathrm{~nm}$, and scanning distance of $15.0 \mathrm{~mm}$. The chemical composition of the pollen was investigated by UK 7421 energy-dispersive X-ray spectroscopy (EDX) (Oxford, UK). The EDX spectrometer was the Link ISIS spectrometer with a $\mathrm{Si}(\mathrm{Li})$ detector, which permitted X-ray detection of elements higher than carbonate $(Z>6)(\mathrm{Lu}$ et al., 2008).

\subsection{Fourier transform infrared spectroscopy (FTIR)}

FTIR allows characterizing the signatures of the overall biochemical composition of the pollen surface through specific spectral features of proteins, lipids, carbohydrates, and cell wall biopolymers. The depth of analysis is about 1 2 $\mu \mathrm{m}$ (Zimmermann, 2010; Zimmermann \& Kohler, 2014).

A Nicolet iS10 in situ diffuse reflectance FTIR spectrometer (Thermo Fisher Scientific, USA) was used to analyze pollen grains. The probe was first cleaned with anhydrous ethanol and the background value was collected without the sample, after which the pollen was tiled on the sample stage and covered with light holes. The measuring range was 4000$400 \mathrm{~cm}^{-1}$ and each sample was recorded to obtain one IR spectrum with a total of 32 scans, and the experimental data were exported with the origin being used for drawing analysis.

\subsection{X-ray photoelectron spectroscopy (XPS)}

XPS was employed to characterize the distribution of chemical elements (carbon-C $1 \mathrm{~s}$, nitrogen-N $1 \mathrm{~s}$, and oxygen-O $1 \mathrm{~s}$ ) on the surface of Platanus pollen grains. The depth of analysis was 8 10 nm (Jimenez et al., 2016; McArthur et al., 2014). A piece of double-sided tape was attached to the aluminum foil. The pollen sample was evenly sprinkled on the tape, and then, a piece of aluminum foil was covered by pressing the tablet using a tablet press. After peeling off the foil, the sample to be tested was placed in the instrument for testing.
The samples were analyzed using monochromatic Al K $\alpha$ with continuously adjustable beam spots from 30 to $400 \mu \mathrm{m}$ in step sizes of $5 \mu \mathrm{m}$. High performance data were collected at low power (72 W) using the CAE scan mode. The full spectrum scan was performed with a pass energy of $100 \mathrm{eV}$ and a step size of $1 \mathrm{eV}$. A narrow-spectrum scan was performed with a pass energy ranging from 30 to $50 \mathrm{eV}$ and a step size ranging from 0.05 to $0.1 \mathrm{eV}$. Scan times were adjusted from 5 to 20 times by combining with power, step length, and signal strength. The surface charge correction for binding energy scale calibration was referenced to the carbon $1 \mathrm{~s}$ core level photoemission peak with a binding energy of $284.8 \mathrm{eV}$. Finally, the data were analyzed using the Thermo Scientific K-Alpha+software (Thermo, USA).

\subsection{Trypan blue staining}

The integrity of the cell membrane can be estimated using the standardized trypan blue staining assay. A pollen suspension was made by dissolving $10 \mathrm{mg}$ of pollen grains in $1 \mathrm{ml}$ of $\mathrm{ddH}_{2} \mathrm{O}$. The pollen suspension was mixed with $100 \mu$ l of $0.4 \%$ trypan blue solution and incubated for $3 \mathrm{~min}$ at $25{ }^{\circ} \mathrm{C}$. The sample was then centrifuged at $1600 \mathrm{~g}$ for $1 \mathrm{~min}$ to recover the pollen grains. After washing twice with $\mathrm{ddH}_{2} \mathrm{O}$, the pollen was dripped onto a slide and covered with a cover slide for observation under a DM 2500 microscope (Leica, Germany). The number of stained pollen grains was counted under ten random fields. The ratio of damaged pollen grains was calculated using the number of dyed pollen compared to the total pollen count. After boiling the pollen suspension for $5 \mathrm{~min}$, the cell membrane becomes destroyed. So all boiled pollen can be dyed blue and used as a positive control in the experiment. The staining analysis experiment was repeated 3 times independently.

\subsection{Extraction of SPPs from pollen grains}

Zhou et al. (2019) described the extraction of SPPs from pollen grains. Briefly, $0.2 \mathrm{~g}$ of Platanus pollen was soaked in $5 \mathrm{ml}$ of $\mathrm{ddH}_{2} \mathrm{O}$. After $6 \mathrm{~h}$, the pollen suspension was centrifuged at $1600 \mathrm{~g}$ for $5 \mathrm{~min}$. Then, the supernatant was centrifuged at $13,000 \mathrm{~g}$ for $15 \mathrm{~min}$ at $4{ }^{\circ} \mathrm{C}$. Finally, the precipitate was dissolved 


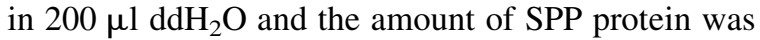
quantified using the Pierce ${ }^{\mathrm{TM}}$ BCA Protein Assay kit (Thermo Fisher, USA).

\subsection{Extraction of Pla a3 protein}

Pollen samples $(0.2 \mathrm{~g})$ were crushed by grinding in liquid nitrogen. Total protein was then extracted using the ProteoPrep ${ }^{\circledR}$ Total Extraction Sample Kit (Sigma-Aldrich, USA). Pla a3 protein concentration was quantified by ELISA according to the standard curve of protein concentration using anti-Pla a3 antibody (NB Biolab, China). Moreover, after sufficient lysis of the SPPs extracted from $0.2 \mathrm{~g}$ of pollen samples, the total protein was extracted and the Pla a3 concentration was quantified.

\subsection{Western blot assay for the identification of Pla a3}

The pollen protein was isolated by SDS-PAGE gel electrophoresis and transferred electrically to the $\mathrm{NC}$ membrane. The NC membrane was immersed in a $1 \%$ BSA solution for $1 \mathrm{~h}$, then rat serum $(1: 100$ dilution) was added and incubated at $37{ }^{\circ} \mathrm{C}$ for $1 \mathrm{~h}$. After washing 3 times ( 5 min each time) with TBST buffer ( $\mathrm{pH} 7.4$ ), the membrane was co-incubated with HRP-labeled secondary antibodies (1:5000 dilution) (YESEN Biotechnology Co. Ltd, China) at $37{ }^{\circ} \mathrm{C}$ for $1 \mathrm{~h}$. Finally, after being washed again with TBST buffer, the reaction was performed with TMB at $37^{\circ}$ $\mathrm{C}$ for $30 \mathrm{~min}$. Protein bands were photographed using a Vilber imaging system (FUSION FX7 Spectra, France). Each sample was detected 3 times. The gray values of the different bands were calculated using ImageJ analysis software. The ratio of Pla a3 protein in each group to the gray value of the corresponding Tublin protein was calculated, and the changes in Pla a3 protein expression in different treatment groups were compared and the histogram drawn using GraphPad Prism5 software. Three independent experiments were repeated.

\subsection{ELISA assay for Pla a3-induced allergenicity}

Briefly, protein samples were dissolved in the embedding buffer $\left(1.59 \mathrm{~g} / \mathrm{L} \quad \mathrm{Na}_{2} \mathrm{CO}_{3}, 2.93 \mathrm{~g} / \mathrm{L}\right.$ $\mathrm{NaHCO}_{3}, \mathrm{pH}$ 9.6), added to the wells of polystyrene plates, and incubated overnight at $4{ }^{\circ} \mathrm{C}$ away from light. The plate was washed three times with PBS buffer ( $\mathrm{pH}$ 7.4), and the anti-rPla a3 IgE antiserum (1:1000 dilution) from sensitized rats (prepared by HuaBio Company, China) was added and incubated overnight at $4{ }^{\circ} \mathrm{C}$. The flushing operation was repeated with PBS, and HRP-labeled secondary antibody (HRP-labeled anti-rat IgE antibody, 1:10,000 dilution, YESEN Biotechnology Co. Ltd, China) was added and incubated at $37{ }^{\circ} \mathrm{C}$ for $1 \mathrm{~h}$. Then, $100 \mu \mathrm{l}$ of freshly concocted tetramethylbenzidine (TMB) substrate solution was added to the color reaction at $37^{\circ} \mathrm{C}$ for $30 \mathrm{~min}$. Finally, $50 \mu \mathrm{l}$ of $2 \mathrm{M}$ sulfate was added to terminate the reaction and detect the $\mathrm{OD}_{450}$ absorbance value with a Bio-Tek microplate reader (Bio-Tek Instruments, USA).

\subsection{Statistical analysis}

All data were statistically analyzed in this study using SPSS version 11.5. Data were obtained from three independent experiments and are shown as mean \pm standard error (SD). Five samples were analyzed per group, and the obtained data should generally conform to a normal distribution. Comparisons between experimental groups were performed using paired Student's $t$-test and ANOVA with SPSS version 11.5. Values of $* p<0.05$ and $* * p<0.01$ were considered statistically significant.

\section{Results}

\subsection{Characterization of pollen morphology}

Scanning electron microscopy data showed different microscopic characterizations of pollen grains sampled in 2019 and 2020 (Fig. 1). It was easily noticed that Platanus pollen grains collected in 2019 absorbed ambient particles more readily than those collected in 2020. In addition, the shape of the pollen grains sampled in 2020 was fuller than that of the 2019 sampled pollen grains.

The results of the trypan blue staining assay demonstrated that the blue-stained pollen was considered to have membrane damage. Comparing the damaged amount of Platanus pollen grains between 2019 and 2020 samples, the 2019 samples had more blue pollens than the 2020 samples (Fig. 2a). The statistical results showed that the percentage of 

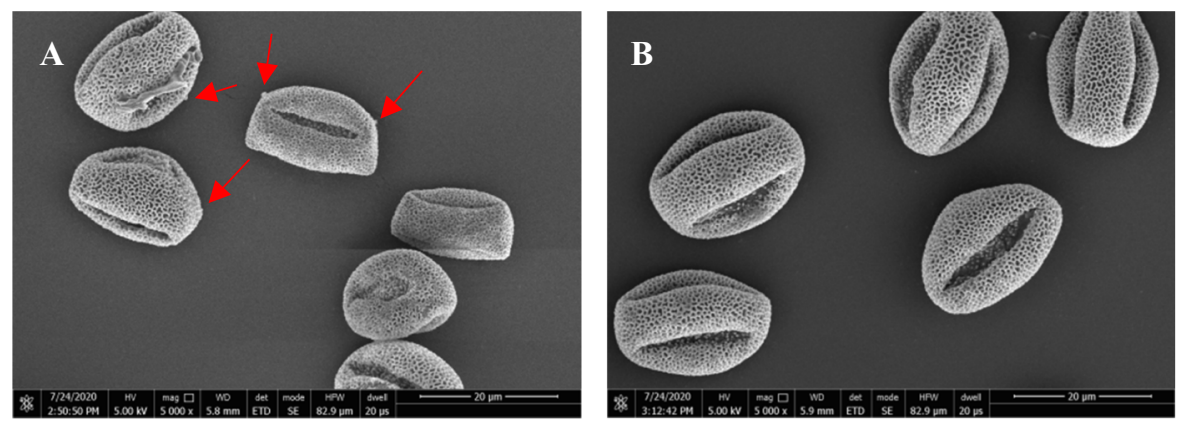

Fig. 1 Scanning electron micrograph of mature Platanus pollen. The pollen sampled at Shangda road in 2019 (a) and 2020 (b), bar= $20 \mu \mathrm{m}$
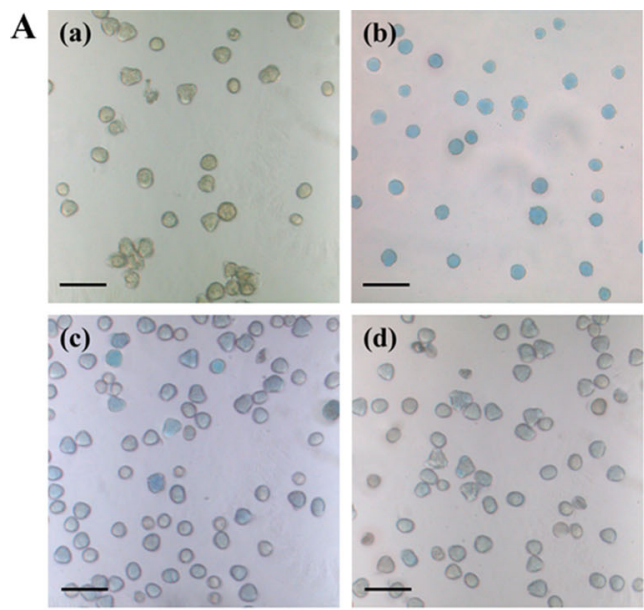

B

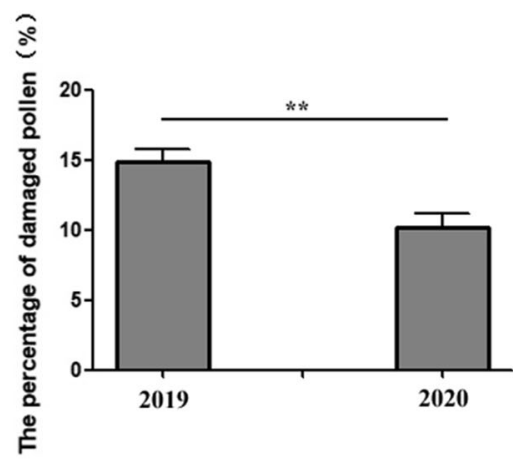

Fig. 2 Observation and statistics of the pollen grains stained by trypan blue. A Microscopic observation of trypan blue staining results, a the pollens without staining, b the boiled pollens were stained by trypan blue, $\mathbf{c}$ the pollens taken in 2019

damaged pollen was $14.88 \%$ in 2019 and $10.12 \%$ in 2020, implying that the pollen cell membrane suffered more serious damage in 2019 than in 2020 (Fig. 2b).

\subsection{Spectroscopic analysis}

Figure 3 shows the different absorption of infrared light for the two different samples collected in 2019 and in 2020. Referring to the lipids' functional groups $\left(1435 \mathrm{~cm}^{-1}\left(-\mathrm{CH}_{3}\right), 1456 \mathrm{~cm}^{-1}\left(-\mathrm{CH}_{2}\right)\right)$, the intensity of the peaks of the lipids in the 2019 samples was stronger than that of the 2020 samples. The same characterization in the peak of the protein (1514 $\mathrm{cm}^{-1}, \quad \beta$-structure; $1541 \mathrm{~cm}^{-1}-\mathrm{CH}_{2}$; $1550 \mathrm{~cm}^{-1}$, amino acid functional groups $-\mathrm{CN},-$ were stained by trypan blue, $\mathbf{d}$ the pollens taken in 2020 were stained by trypan blue. B Statistical analysis of trypan blue staining pollen in 2019 and 2020. Bar $=50 \mu \mathrm{m}(* * p<0.01)$

$\mathrm{NH})$, Lipid (1435 $\left.\mathrm{cm}^{-1},-\mathrm{CH}_{3} ; 1456 \mathrm{~cm}^{-1},-\mathrm{CH}_{2}\right)$, sporopollenin $\left(814 \mathrm{~cm}^{-1}, 839 \mathrm{~cm}^{-1}, 866 \mathrm{~cm}^{-1}\right.$, $\left.890 \mathrm{~cm}^{-1}-\mathrm{CH}\right)$, and carbohydrate $\left(991 \mathrm{~cm}^{-1},-\mathrm{CH}\right.$; $\left.1025 \mathrm{~cm}^{-1},-\mathrm{CN} ; 1166 \mathrm{~cm}^{-1}, \mathrm{C}-\mathrm{O}-\mathrm{C}\right)$ could be found in the measured samples. These data are an indication that air pollutants can change the composition of pollen walls.

It is well known that the position of an XPS peak depends on the chemical state of the element. There is a tendency for the binding energy to decrease with increasing electron density on the atom and, in simple cases, with decreasing degree of oxidation. The XPS surface analysis of Platanus pollen samples in 2019 and 2020 (Fig. 4) showed the presence of the main types of linked atoms, whose relative percentage in the $\mathrm{C} 1 \mathrm{~s}, \mathrm{~N} 1 \mathrm{~s}$ and $\mathrm{O} 1 \mathrm{~s}$ spectra were not significantly 

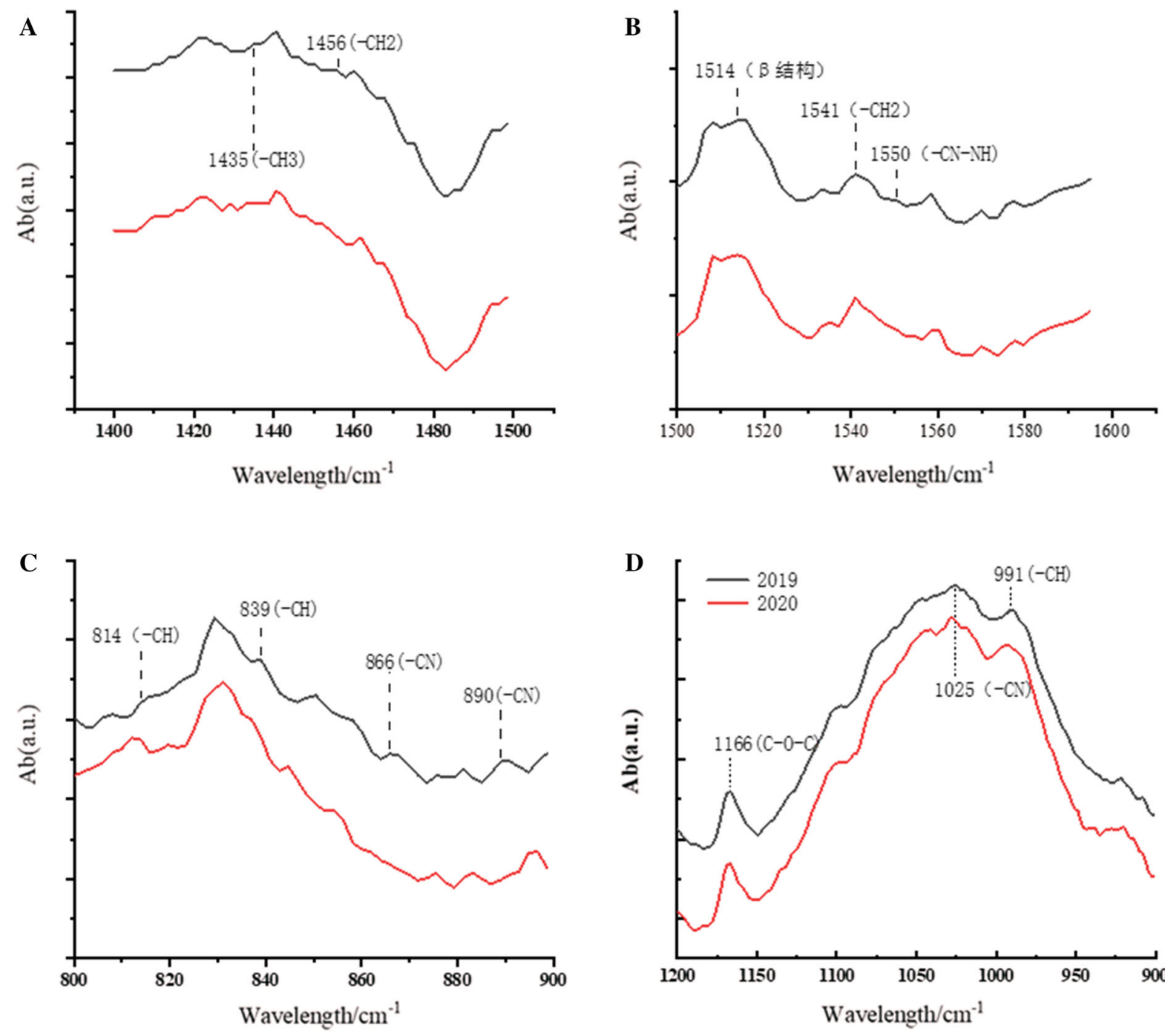

Fig. 3 Fourier infrared spectroscopy (FTIR) of Platanus pollen grains in 2019 (black line) and 2020 (red line). Group distribution: $1514 \mathrm{~cm}^{-1}$ ( $\beta$ structure), $1541 \mathrm{~cm}^{-1}(-\mathrm{CH} 2)$, $1550 \mathrm{~cm}^{-1}$ (amino acid functional groups $-\mathrm{CN},-\mathrm{NH}$ ),

different (Table 1). There were no obvious changes in the binding energies of the high-resolution group of the 2-year samples. However, the relative content of each component was slightly different.

The C1s core level spectrum of pollen grains collected in 2019 can be divided into three parts: (I) Carbon only bound to carbon and hydrogen $(\mathrm{C}-\mathrm{C}$ \& $\mathrm{C}-\mathrm{H}$ ) at $284.80 \mathrm{eV}$, (II) carbon forming a single bond with oxygen or nitrogen $(\mathrm{C}-\mathrm{O}, \mathrm{N})$ at $285.57 \mathrm{eV}$, and (III) carbon forming two single bonds or one double bond with oxygen $(\mathrm{O}-\mathrm{C}=\mathrm{O})$ at $288.63 \mathrm{eV}$.

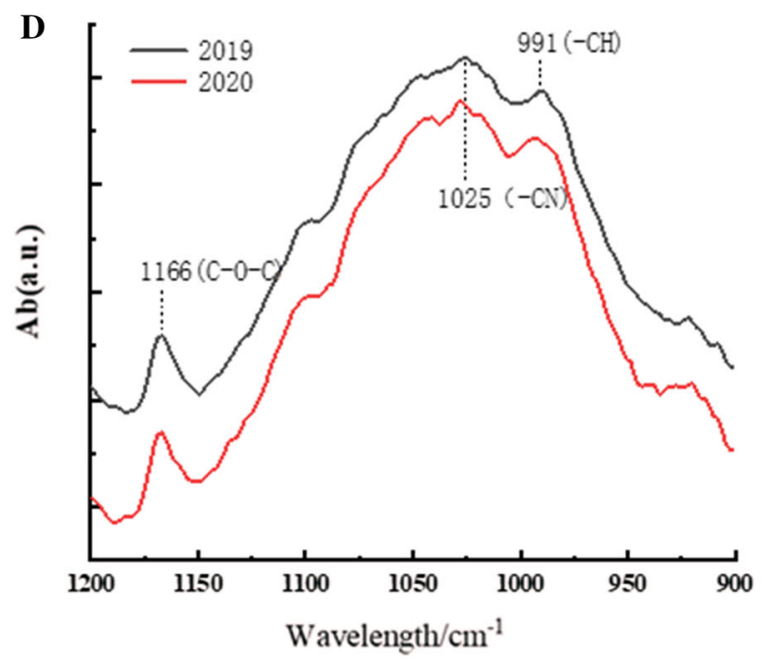

$1435 \mathrm{~cm}^{-1}$ (-CH3), $1456 \mathrm{~cm}^{-1}$ (-CH2), $814 \mathrm{~cm}^{-1}, 839 \mathrm{~cm}^{-1}$, $866 \mathrm{~cm}^{-1}, 890 \mathrm{~cm}^{-1}(-\mathrm{CH}), 991 \mathrm{~cm}^{-1}(-\mathrm{CH}), 1025 \mathrm{~cm}^{-1}$ ($\mathrm{CN}), 1166 \mathrm{~cm}^{-1}(\mathrm{C}-\mathrm{O}-\mathrm{C})$

The spectra of pollen grains sampled in 2020 showed that the binding energy was not sufficient to cause changes in the chemical state of the elements, so there is no significant change in the $\mathrm{C} 1 \mathrm{~s}$ core level spectrum of pollen grains collected in 2020.

The O1s core level spectrum forms a double bond $(\mathrm{C}=\mathrm{O})$ with oxygen at a lower binding energy $(531.5 \mathrm{eV}-532 \mathrm{eV})$ and a single bond $(\mathrm{C}-\mathrm{O})$ with oxygen at a higher binding energy $(\sim 533 \mathrm{eV})$ from the spectrum of the pollen grains. 

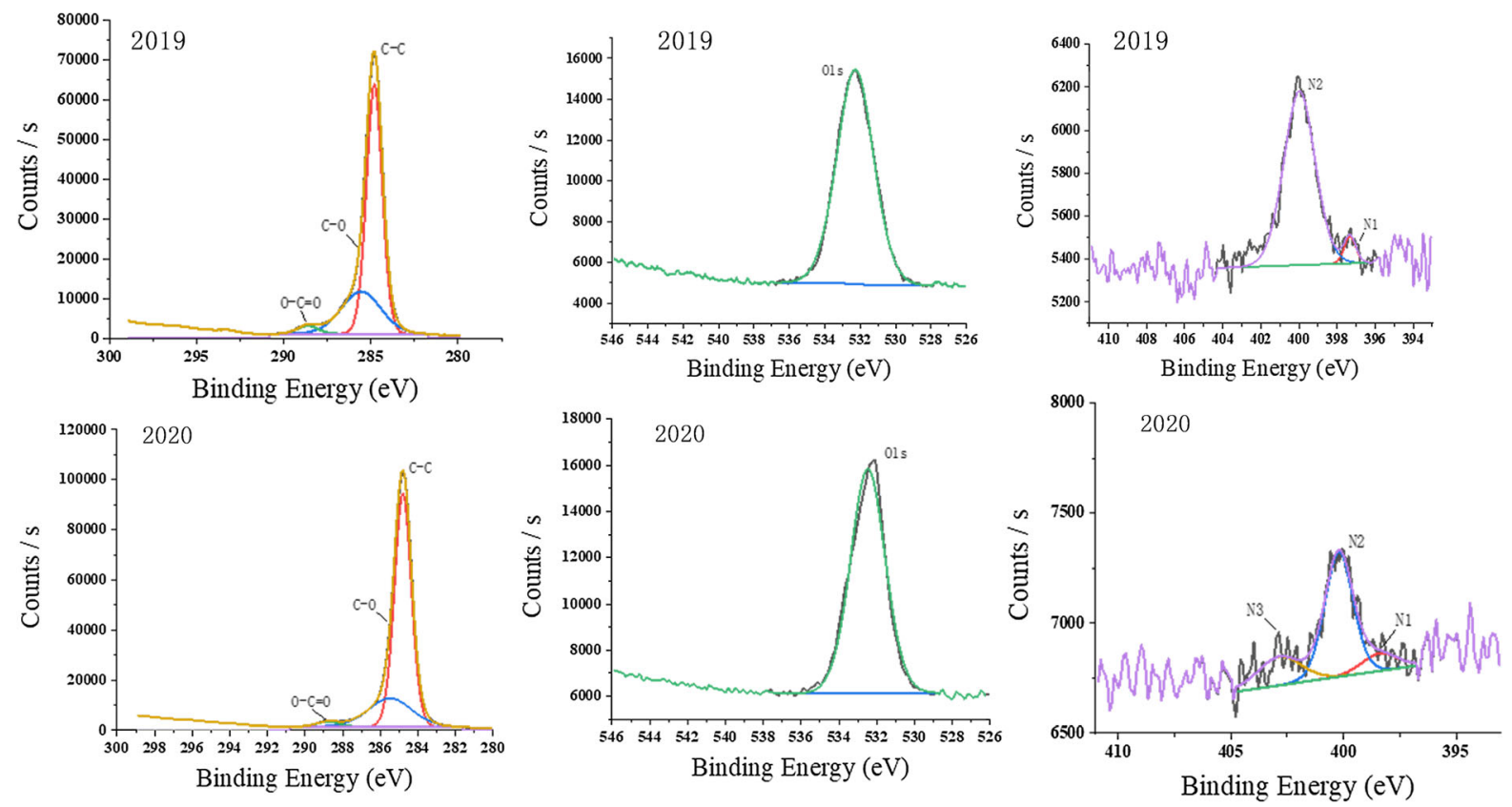

Fig. 4 C 1 s, O 1 s and N 1 s core level XPS spectra of Platanus pollen grains sampled in the spring of 2019 and 2020

Table 1 The measured C $1 \mathrm{~s}, \mathrm{O} 1 \mathrm{~s}$ and N 1 s spectra can be resolved into their spectral components through curve fitting

\begin{tabular}{llllll}
\hline Functionality & \multicolumn{2}{l}{2019 年 } & & \multicolumn{2}{c}{ 2020年 } \\
\cline { 2 - 3 } \cline { 5 - 6 } & Peak BE $(\mathrm{eV})$ & Relative abundance & & Peak BE (eV) & Relative abundance \\
\hline $\mathrm{C}-\mathrm{C}$ & 284.80 & $60.73 \%$ & 284.80 & $69.56 \%$ \\
$\mathrm{C}-\mathrm{O}$ & 285.57 & $25.93 \%$ & 285.47 & $21.76 \%$ \\
$\mathrm{O}-\mathrm{C}=\mathrm{O}$ & 288.63 & $2.61 \%$ & 288.79 & $1.93 \%$ \\
$\mathrm{O} 1 \mathrm{~s}$ & 532.28 & $9.12 \%$ & 532.46 & $5.8 \%$ \\
$\mathrm{~N} 1 \mathrm{~s}$ & 397.32 & $0.09 \%$ & 398.39 & $0.11 \%$ \\
& 399.97 & $1.50 \%$ & 400.20 & $0.63 \%$ \\
\hline
\end{tabular}

As a result, the $\mathrm{N} 1 \mathrm{~s}$ core level spectrum revealed a high spectral noise due to the low $\mathrm{N}$ content, and we found a lower pollen nitrogen concentration in 2020 $(0.96 \%)$ than in the 2019 samples $(1.59 \%)$. The nitrogen bonding became more heterogeneous after exposure to gaseous pollutants. However, the relative content of each component of the two samples showed that the nitrogen concentration of pollen samples increased in 2019, and the peptide chain content was also higher than that of pollen samples in 2020, indicating an increase in protein surface concentration (Jimenez et al., 2016; Ribeiro et al., 2017).

\subsection{Immunochemical analysis}

Based on the quantitative results of the BCA assay, the mass concentrations of the extracted proteins from the pollen samples collected in 2019 and 2020 were diluted to the same level. Then, the result of the western blot assay showed that although the concentration of Tublin protein bands reflected that the total protein content of the 2020 samples was significantly higher than that of 2019, the concentration of Pla a3specific bands was significantly lower than that of the 2019 samples (Fig. 5a). The gray values of different bands were calculated using ImageJ analysis software. The ratio of the Pla a3 protein in each group to 
Fig. 5 a Western blot of Platanus pollen extract in 2019 and 2020 with rabbit serum $\mathrm{IgG}$; b gray value analysis of Platanus pollen protein $(* * P<0.01)$
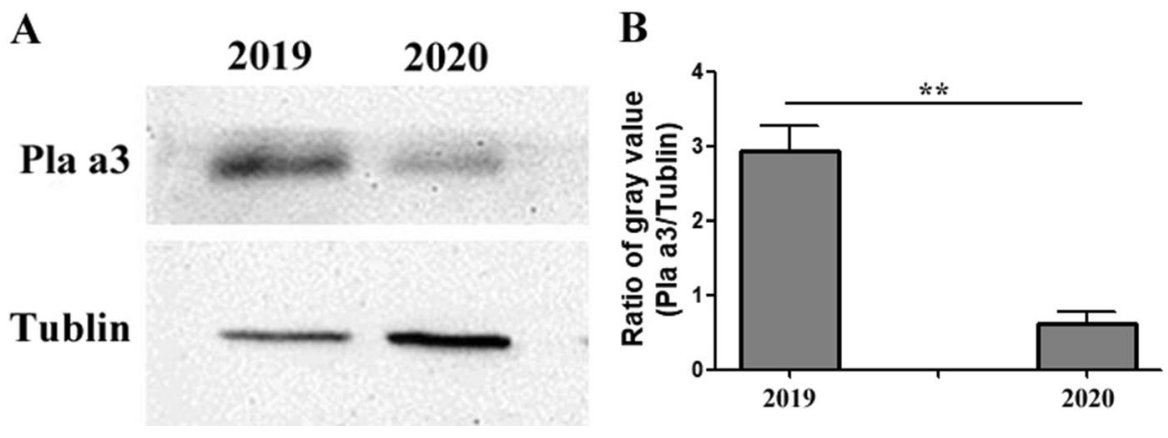

the gray value of the corresponding Tublin protein was calculated to compare the changes in Pla a3 protein expression in different treatment groups. Figure $5 \mathrm{~b}$ shows that the gray value ratio of Pla a3 protein to Tublin protein in pollen was significantly greater in 2019 than in 2020 ( $p<0.01$, statistically significant). This indicates that the 2019 pollen grains releases more Pla a3 protein content. With reference to the OD450-Pla a3 standard curve to be calculated, the content of the Pla a3 allergenic protein in the total pollen protein and the SPPs released by Platanus pollen were measured by ELISA. The experimental results are shown in Fig. 6. The expression of Pla a3 protein was significantly higher in the 2019 sample than in the 2020 pollen $(p<0.01$, statistically significant). The data are consistent with the results of the western blot experiment.

\section{Discussion}

Air pollutants are believed to induce airway inflammation and play a key role in respiratory allergies

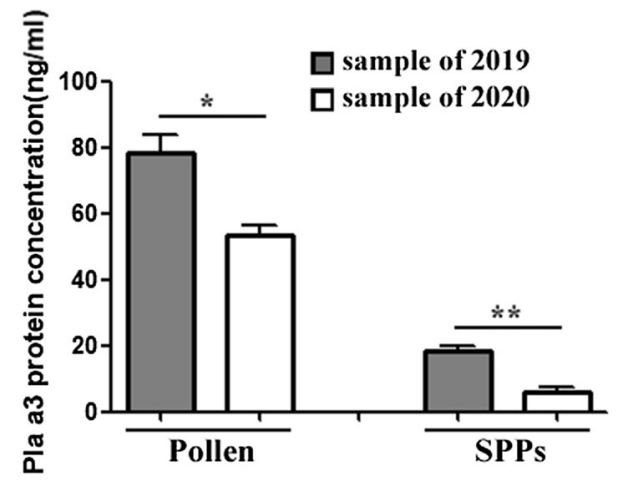

Fig. 6 ELISA detection of total Platanus pollen protein and SPPs with rabbit serum IgG antibody $(* p<0.05$, $* * p<0.01)$
(Leung et al., 2012). Furthermore, with the rapid economic development in China, the mass levels of air pollutants such as $\mathrm{NOx}, \mathrm{O}_{3}$, and PMs in the urban atmosphere have increased dramatically. In addition, exposure to airborne pollen and air pollutants can greatly enhance the incidence of allergic respiratory diseases (D'Amato et al., 2015). Our previous research demonstrated that the pollen membranes were more severely damaged and the expression of allergenic proteins (Pla a3) increased significantly after exposure of Platanus pollen grains to different air pollutants $\left(\mathrm{NO}_{2}, \mathrm{O}_{3}, \mathrm{NO}_{2}\right.$ and $\mathrm{O}_{3}$ mixture) ( $\mathrm{Lu}$ et al., 2014). Data from our pollen-sensitized model also showed that $\operatorname{IgE}$ and $\operatorname{IgG}$ levels in the blood of exposed mice were increased after their exposure to air pollutants (Zhou et al., 2021).

As a result of the COVID-19 outbreak, citizens were required to stay in their homes and industrial activities ceased at the end of January 2020. These control measures contributed to the improvement in air quality. Concentrations of $\mathrm{PM}_{2.5}, \mathrm{NO}_{2}$, and $\mathrm{SO}_{2}$ decreased significantly (Wang et al., 2020). As the pandemic was brought under control, the government allowed some industrial enterprises to resume work from late February 2020, resulting in a slight increase in the mass levels of air pollutants ( $\mathrm{Li}$ et al., 2020; $\mathrm{Wu}$ et al., 2021). Our sampling campaign last from April 5 to April 20. During the sampling period, there was no significant decrease in the mass levels of major pollutants such as $\mathrm{PM}_{2.5}, \mathrm{PM}_{10}$, and $\mathrm{O}_{3}$, but the mass level of $\mathrm{NO}_{2}$ decreased in 2020 compared to 2019 (Figure S2). This work was carried out considering that atmospheric pollution causes a decrease in pollen viability and germination (Senechal et al., 2015). Our data clearly showed that the biological activity of Platanus pollen grains sampled in 2020 was more active than in 2019 (Fig. 3). Allergenic 
protein expression from pollen grains collected in 2020 decreased significantly compared to that of 2019 (Fig. 6). Motta et al. (2006) once reported that morphological damages were observed after exposure of $P$. pratense pollen grains to several concentrations of $\mathrm{NO}_{2}(50 \mathrm{ppm})$ and $\mathrm{O}_{3}(0.5 \mathrm{ppm})$; moreover, the amount of pollen cytoplasmic granules released from pollen grains increased compared to the control (Motta et al., 2006). Ghiani et al. (2012) also claimed that ragweed pollen proteins collected near hightraffic roads reacted more intensely with $\operatorname{IgE}$ (patients) than the control (Ghiani et al., 2012). This result may suggest that interactions between air pollutants and allergenic pollen can enhance their allergenicity. We once demonstrated that the allergenicity of Platanus pollen protein Plaa3 increased after exposure to $\mathrm{NO}_{2}$ and $\mathrm{O}_{3}$. In this study, Pla a3 protein exacted from Platanus pollen grains collected in 2019 and 2020 reacted with rabbit serum IgG using an ELISA assay. The gray values of Platanus pollen protein from 2019 pollen grains and 2020 samples were 2.92 and 0.60 , respectively, indicating a higher binding capacity of Pla a 3 from 2019 samples and suggesting that air pollutants promote $\left(\mathrm{O}_{3}\right.$ and $\left.\mathrm{NO}_{2}\right)$ the binding capacity of Pla a3. Helena et al. (2017) studied the effects of two important atmospheric pollutants $\left(\mathrm{O}_{3}\right.$ and $\left.\mathrm{NO}_{2}\right)$ on the allergenic properties and chemical composition of Platanus acerifolia pollen. Their immunochemical analysis data showed that the variety of pollen allergenicity differed based on the exposure of the two different pollutants (gas or mixture of gases) tested and that the same pollutant gas may interact differently with each specific allergen. The spectroscopic (FTIR and XPS) results show that air pollutants alter the components of the pollen wall and further compromise pollen function (Ribeiro et al., 2017).

Our FTIR and XPS analysis data also indicate that air pollutants (such as $\mathrm{NO}_{2}$ ) may change the composition of the pollen wall and lead to increased protein concentrations on the pollen surface, which suggests that higher mass levels of $\mathrm{NO}_{2}$ in the spring of 2019 contribute to the release of $\mathrm{Pla}$ a 3 from pollen grains.

Allergenicity caused by allergenic pollen correlates with airborne pollen and/or atmospheric concentrations of allergens. The mass level of aeroallergens is associated with many factors, such as air pollutants, air temperature, humidity, and precipitation. It is noted that only humidity has a significant difference $(67.20 \pm 12.49$ in $2019 ; 63.11 \pm$ 11.64 in 2020) in the sampling period among meteorological parameters (air temperature, humidity, wind speed, and air pressure) (supplementary materials, Figures S3, S4). Considering that humidity contributes to the release of SPPs/allergens (Wang et al., 2012), the allergenicity induced by Platanus pollen protein may be stronger in 2019 than in 2020, and further studies are needed.

\section{Conclusions}

(1) Platanus pollen grains were collected in the spring of 2019 and 2020. The biological activity of pollen collected in 2019 decreased compared to that collected in 2020 .

(2) FTIR analysis data demonstrated that the functional groups with reference to lipids were more prominent in the pollen collected in 2020; however, the functional groups with reference to proteins had greater absorption peak intensity in the pollen collected in the spring of 2019, thus reflecting changes in the composition of the pollen wall by atmospheric pollutants. The XPS data showed no significant change in the binding energy of the high-resolution components of the two-year samples, but the relative content of nitrogen and peptide chains in pollen samples from pollen grains collected in 2019 was higher than that in 2020, indicating an increase in the concentration of pollen proteins on pollen grains.

(3) Data from Western blot and ELISA assays demonstrated that the amount of SPPs extracted from Platanus pollen grains collected in 2019 was significantly higher than that in 2020 .

Acknowledgements This research was funded by the Science and Technology Committee of Shanghai (20ZR1419500; 21DZ1202300); Natural Science Foundation of China (NSFC Grant No. 21477073).

Author contributions S.L. and S.Z. designed the study, instructed all experiments. S.Z. drafted the manuscript. X.W. carried out animal experiment, M.T. and X. K. were responsible for exposure experiment. Z.L. analyzed the data of Pla a3 protein. W. Z and S.L. provided instruction on 
allergenic reaction. X. L, W.W. and W.Q. revised the manuscript.

\section{Declarations}

Conflict of interest All authors confirm there are no potential conflicts of interest should be disclosed.

\section{References}

Acciani, T. H., Brandt, E. B., Hershey, G. K. K., et al. (2013). Diesel exhaust particle exposure increases severity of allergic asthma in young mice. Clinical and Experimental Allergy, 43(12), 1406-1418.

Arilla, M. C., Ibarrola, I., Mir, A., et al. (2005). Development of a sandwich-type ELISA for measuring Pla a1, the major allergen of Platanus acerifolia pollen. International Archives of Allergy and Immunology, 138, 127-133.

Asturias, J. A., Ibarrola, I., Bartolomé, B., et al. (2002). Purification and characterization of $\mathrm{Pla}$ a 1 , a major allergen from Platanus acerifolia pollen. Allergy, 57, 221227.

Chauhan, S. V., Chaurasia, B., \& Rana, A. (2004). Impact of air pollution on flfloral morphology of Cassia siamea Lamk. Journal of Environmental Biology, 25(3), 291-297.

Chehregani, A., Majde, A., Moin, M., et al. (2004). Increasing allergy potency of Zinnia pollen grains in polluted areas. Ecotoxicology and Environmental Safety, 58(2), 267-272.

D’Amato, G., Cecchi, L., Bonini, S., Nunes, C., Annesi-Maesano, I., Behrendt, H., Liccardi, G., Popov, T., \& van Cauwenberge, P. (2007). Allergenic pollen and pollen allergy in Europe. Allergy, 62, 976-990.

D’Amato, G., Holgate, S. T., Pawankar, R., et al. (2015). Meteorological conditions, climate change, new emerging factors, and asthma and related allergic disorders. A statement of the world allergy organization. World Allergy Organization Journal, 8(1), 25.

Dahl, A. (2018). Pollen lipids can play a role in allergic airway inflammation. Frontiers in Immunology, 9(2816), 2018. https://doi.org/10.3389/fimmu.2018.02816.eCollection

Fernández, M., Guedes, A., Gbreuc, A., \& Rodríguez-Rajo. (2013). Pla a_1 aeroallergen immunodetection related to the airborne Platanus pollen content. Science of The Total Environment, 463-464, 855-860.

Ghiani, A., Aina, R., \& Asero, R. (2012). Ragweed pollen collected along high traffic roads shows a higher allergenicity than pollen sampled in vegetated areas. Allergy, 67(7), 887-894.

Griffifiths, J., Woodyatt, A. (2020). 780 million people in China are living under travel restrictions due to the coronavirus outbreak. https://www.cnn.com/2020/02/16/ asia/coronavirus-covid-19-death-toll-update-intl-hnk/in dex.html.

Hong, Q., Zhou, S. M., Zhao, H., et al. (2018). Allergenicity of recombinant Humulus japonicus pollen allergen 1 after combined exposure to ozone and nitrogen dioxide. Environmental Pollution, 234, 707-715.
Hu, Y., Xu, Z., Jiang, F., Li, S., Liu, S., Wu, M., Yan, C., Tan, J., Yu, G., Hu, Y., Yin, Y., \& Tong, S. (2020). Relative impact of meteorological factors and air pollutants on childhood allergic diseases in Shanghai, China. Science of the Total Environment. https://doi.org/10.1016/j.scitotenv. 2019.135975

Jimenez-Relinque, E., Sapina, M., Nevshupa, R., et al. (2016). Photocatalytic decomposition of pollen allergenic extracts of Cupressus arizonica and Platanus hybrida. Chemical Engineering Journal, 286, 560-570.

Leung, T. F., Ko, F. W., \& Wong, G. W. (2012). Roles of pollution in the prevalence and exacerbations of allergic diseases in Asia. The Journal of Allergy and Clinical Immunology, 129, 42-47.

Li, L., Li, Q., Huang, L., Wang, Q., Zhu, A., Xu, J., Zi, Liu, et al. (2020). Air quality changes during the COVID-19 lockdown over the Yangtze river delta region: An insight into the impact of human activity pattern changes on air pollution variation. Science of the Total Environment, 732, 139282.

Lu, S., Yao, Z., Chen, X., Wu, M., Sheng, G., Fu, J., \& Daly, P. (2008). Physicochemical characterization and potential toxicity of fine particulate matter (PM2.5) in Shanghai atmosphere. Atmospheric Environment, 42, 7205-7214.

Lu, S., Ren, J., Hao, X., Liu, D., Zhang, R., Wu, M., Yi, F., Lin, J., Shinich, Y., \& Wang, Q. (2014). Characterization of protein expression of Platanus pollen following exposure to gaseous pollutants and vehicle exhaust particles. Aerobiologia, 30, 281-291.

McArthur, S. L., Mishra, G., \& Easton, C. D. (2014). Applications of XPS in biology and biointerface analysis. Surface analysis and techniques in biology (pp. 9-36). Cham: Springer.

Motta, A. C., Marliere, M., \& Peltre, G. (2006). Traffic-related air pollutants induce the release of allergen-containing cytoplasmic granules from grass pollen. International Archives of Allergy and Immunology., 139(4), 294-298.

Ribeiro, H., Costa, C., Abreu, I., et al. (2017). Effect of O3 and $\mathrm{NO} 2$ atmospheric pollutants on Platanus $\mathrm{x}$ acerifolia pollen: Immunochemical and spectroscopic analysis. Science of the Total Environment, 599, 291-297.

Senechal, H., Visez, N., Charpin, D., et al. (2015). A Review of the effects of major atmospheric pollutants on pollen grains, pollen content, and allergenicity. The ScientificWorld Journal, 2015, 940243.

Suárez-Cervera, M., Asturias, J. A., Vega-Maray, A., et al. (2005). The role of allergenic proteins Pla a 1 and Pla a 2 in the germination of Platanus acerifolia pollen grains. Sexual Plant Reproduction, 18, 101-112.

Tashpulatov, A. S., Clement, P., \& Akimcheva, S. A. (2004). A model system to study the environment-dependent expression of the Bet $\mathrm{v}$ 1a gene encoding the major birch pollen allergen. International Archives of Allergy and Immunology, 134(1), 1-9.

Wang, Q., \& Su, M. (2020). A preliminary assessment of the impact of COVID-19 on environment - A case study of China. Science of the Total Environment, 728, 138915.

Wang, Q., Nakamura, S., Lu, S., Xiu, G., Nakajima, D., Suzuki, M., Sakamoto, K., \& Miwa, M. (2012). Release behaviour of small sized daughter allergens from 
Cryptomeria japonica pollen grains during urban rainfall event. Aerobiologia, 28, 71-81.

Wang, L., Li, M., Yu, S., et al. (2020). Unexpected rise of ozone in urban and rural areas, and sulfur dioxide in rural areas during the coronavirus city lockdown in Hangzhou, China: Implications for air quality. Environmental Chemistry Letters, 12, 1-11.

Wu, C., Wang, H., Cai, W., He, H., Ni, A., \& Peng, Z. (2021). Impact of the COVID-19 lockdown on roadside trafficrelated air pollution in Shanghai, China. Building and Environment, 194, 107718.

Xu, H., Zhong, L., Deng, J. X., et al. (2020). High expression of ACE2 receptor of 2019-nCoV on the epithelial cells of oral mucosa. International Journal of Oral Science, 12(1), 8.

Zhao, F., Elkelish, A., Durner, J., Lindermayr, C., Winkler, J. B., Ruëff, F., Behrendt, H., Traidl-Hoffmann, C., Holzinger, A., Kofler, W., Braun, P., von Toerne, C., Hauck, S. M., Ernst, D., \& Frank, U. (2016). Common ragweed
(Ambrosia artemisiifolia L.): Allergenicity and molecular characterization of pollen after plant exposure to elevated NO2. Plant, Cell and Environment, 39, 147-164.

Zhou, S. M., Zhao, H., Peng, J. X., et al. (2019). Size distribution of Platanus acerifolia allergen 3 (Pla a3) in Shanghai ambient size-resolved particles and its allergenic effects. Atmospheric Environment, 198, 324-334.

Zhou, S., Wang, X., Lu, S., Yao, C., Zhang, L., Rao, L., Liu, Zhang, Li, \& Wang, Q. (2021). Characterization of allergenicity of Platanus pollen allergen a 3 (Pla a 3 ) after exposure to NO2 and O3. Environmental Pollution, 278, 116913.

Zimmermann, B. (2010). Characterization of pollen by vibrational spectroscopy. Applied Spectroscopy, 64(12), 13641373.

Zimmermann, B., \& Kohler, A. (2014). Infrared spectroscopy of pollen identifies plant species and genus as well as environmental conditions. PLoS One, 9(4), e95417. 